\title{
Growth and Yield of Rice (Oryza sativa L.) under Raised- and Sunken-Bed System as Affected by Saline Irrigation in Baros, Bantul, Yogyakarta
}

\author{
Nafi'atul Muflikhah*, Budiastuti Kurniasih and Tohari \\ Department of Agronomy, Faculty of Agriculture, Universitas Gadjah Mada \\ Jln. Flora no. 1, Bulaksumur, Sleman, Yogyakarta 5528, Indonesia \\ *Corresponding email: tuti_b@ugm.ac.id
}

\begin{abstract}
The utilizing marginal land (e.g. saline field) is expected able to increase rice production under saline condition. The raised- and sunken-bed system as an integrated approach can be applied for thus condition. This experiment aimed to investigate the growth and yield of rice under raised- and sunken-bed system as affected by saline irrigation. The experiment was arranged in a multi-location (oversite) design, consisted of saline irrigation (S1) and nonsaline irrigation (S0) in a raised-bed (A1) and sunken-bed (A0) planting system. The observations were done on leaf area index, chlorophyll $a$, chlorophyll $b$, total chlorophyll, photosynthesis rate, total dry weight, root length, leaf $\mathrm{Na}^{+}$and $\mathrm{K}^{+}$concentration, proline concentration, maturity and dry grain yield (DGY). The results showed that saline irrigation negatively affected the leaf area index, photosynthetic rate and the root length of rice grown at sunken-bed. However, the leaf $\mathrm{Na}^{+}$concentration and leaf proline concentrations of rice grown at sunken-bed were higher than in raised-bed. The leaf $\mathrm{K}^{+}$ concentration decreased with increasing $\mathrm{Na}^{+}$concentration. Although the saline irrigation could accelerate the harvesting age of rice grown at sunken-bed, the dry grain yield of rice grown at sunken-bed did not significantly different with that of rice grown at raised-bed.
\end{abstract}

Keywords: Rice (Oryza sativa L.), Salinity, Raised-bed, Sunken-bed

\section{INTRODUCTION}

Rice is the main staple food in Indonesia and some countries. Saline soils and saline water are becoming major constraints affecting rice production and quality (Chinnusamy et al., 2005). Rice is generally considered as a salt-sensitive plant. Substantially, salinity stress may reduce rice yield, but its response varies among varieties (Shannon et al., 1998). It also depends on the intensity and duration of salinity stress (Zeng et al., 2001). The value of electrical conductivity (EC) provides more accurate information about soil salinity. The value measured in $\mathrm{mScm}-1$ gives an indication of the amount of electrolyte in the soil solution. The higher the value, the more salt contained in the solution (FAO, 2005). Munns and Tester (2008) classified a saline soil if its EC value is $4 \mathrm{dS} \mathrm{m}-1$ or more. The declination in land productivity especially in coastal areas as affected by salinity is one of constrains in order to increase rice production. The decrease of paddy field productivity in mangrove area of Bantul is an example where by the intrusion of sea water to the land area caused salt accumulation in soils dominated by sodium chloride $(\mathrm{NaCl})$ which was able to inhibit growth and production of rice. The soil salinity stresses a plant in two ways. High concentrations of salt in the soil make it harder for roots to extract water, and high concentrations of salts within the plant can be toxic (Munns \& Tester, 2008). Levitt (1980) informed that the high $\mathrm{NaCl}$ in the saline area also contributed to nutrient deficiency. The amount of $\mathrm{Na}^{+}$in the soil lowered the availability of $\mathrm{Ca}^{2+}$, $\mathrm{Mg}^{2+}$, and $\mathrm{K}+$ that can be absorbed by the rice plant. Rezaei et al. (2011) said that saline irrigation relatively for a long period will cause the salt accumulation of in the soil and will damage the plant.

The tide that commonly occurs in the full moon and dry season inhibit the growth of rice because the rice fields are usually flooded. Tidal waves that occur on agricultural land for long periods can cause the land to be flooded with water containing high salinity (Shaaban et al., 2013). At the meantime, most 
of land in the mangrove area of Bantul Regency is intentionally abandoned until weeds are overgrown. Due to this condition, the land is only grown once a year with low yield and the farmers are unable to cover production costs. According to these conditions, the urgent attention is required by utilizing marginal land which is expected to increase rice production as well as farmers can grow rice still. One of integrated approaches that can be applied is raised- and sunkenbed system.

Raised-bed and sunken bed system is a package of technologies that adaptive and mitigate against climate change. It is adaptive because the technological components in this system have adapted to climate change. There are an elevated parts (raised-bed) and excavated parts (sunked-bed) that anticipate farmers against the risks of drought and floods including tidal wave (Atamaja, 2013). The raised-bed and sunken-bed direction is recommended from east to west so that the crops will receive sufficient sun exposure. To maintain its form and productivity (Nazemi et al., 2013).

Situ Bagendit is one of the varieties of upland rice, but is able to grow well in the wetland environment. The ability of Situ Bagendit can adapt in dry and wetland environment be an option for farmers Bantul who still want to do the planting using local varieties. Rice planting with saline irrigation can still be done by applying in the dry parts (raised-bed) and wet part (sunken-bed). So it can increase the rice production of farmers in case of tidal wave and salinity stress. In the previous research, the variety of Situ Bagendit showed better results compared than IR-64 cultivars at saline irrigation. The grain yield of Situ Bagendit was better than IR-64. Situ Bagendit variety have decreased yield by 37\% while IR-64 experienced a decrease of $47.5 \%$ of potential yield (Hasanah, 2016).This experiment aimed to investigate the growth and yield of rice under raised- and sunken-bed system as affected by saline irrigation.

\section{MATERIALS AND METHODS}

The primary materials used in this research were the 'Situ Bagendit' seed (improved rice variety for upland), organic fertilizer, NPK fertilizer $(15 \% \mathrm{~N}$, $15 \% \mathrm{P}_{2} \mathrm{O}_{5}, 15 \% \mathrm{~K}_{2} \mathrm{O}$, and $10 \% \mathrm{~S}$ ) and groundwater (EC 4-5 dSm $\left.{ }^{-1}\right)$. Organic fertilizer aplicated before rice planted with 20 ton.ha ${ }^{-1}$. Watering done two times a day or adjusted to the conditions of plants in the field.

This experiment was conducted at Baros, Bantul District, Yogyakarta from October 2016 to February
2017. The experiment was arranged in multi-location (oversite) design, consisted of saline irrigation (S1) and nonsaline irrigation (S0) in a raised-bed (A1) and sunken-bed (A0) planting system.

Raised- and sunken-bed system at saline or nonsaline irrigation are assumed to be different locations because the characteristics of raised- and sunken-bed are different, for example from the characteristics of the soil height and irrigation water level.

Rice planted at 20x20 cm spacing. The observations were done on leaf area index (LAI) (Gardner et al.,1991); chlorophyll a, chlorophyll b and total chlorophyll; photosynthesis rate (Sunghening, 2015); total dry weight; root length (Tohari, 2017); leaf $\mathrm{Na}^{+}$and $\mathrm{K}^{+}$concentration (Munns, et al., 2010); proline concentration; maturity and dry grain yield (DGY). The data were analyzed using Analysis of Variance (ANOVA) and followed by comparison of means using Tukey's HSD test at 5\% significance level. All data were analyzed by using SAS portable program version 9.1.3.

\section{RESULTS AND DISCUSSION}

Average rainfall during the present experiment was $441.4 \mathrm{~mm} \mathrm{month}^{-1}$. Average rainfall during October was $324 \mathrm{~mm}$ month $^{-1}$. The intensity of rainfall was increasing from November to December. The rainfall peaked in December with an average of $708 \mathrm{~mm} \mathrm{month}^{-1}$, then decreased in January and increased again in February with an average of 361 $\mathrm{mm}$ month $^{-1}$. The highest light intensity also occurred in December (2,677 lux) and the lowest one occurred in November (1,093 lux). The highest temperature found in February $\left(33.05^{\circ} \mathrm{C}\right)$ and the lowest temperature was in November $\left(29.03^{\circ} \mathrm{C}\right)$. The average humidity and wind speed during the experiment were $71.27 \%$ and $4.06 \mathrm{~km} \mathrm{~h}^{-1}$, respectively (Table 1 ).

The electrical conductivity (EC) of irrigation water used from the beginning to the end of the experiment fluctuated. It was presumably due to low and high rainfall. The highest EC value $\left(6.05 \mathrm{dSm}^{-1}\right)$ occurred at 10 weeks after planting (WAP). The high EC value was suspected as affected by the accumulation from previous irrigation and low rainfall. The mean of EC from saline water during the experiment was $2.14 \mathrm{dSm}^{-1}$. Soil EC measured at sunken-bed from the beginning to the end of experiment showed a higher value than that at raised-bed. The soil EC value increased at $10 \mathrm{WAP}\left(8.75 \mathrm{dSm}^{-1}\right)$ and decreased to $0.48 \mathrm{dSm}^{-1}$. The increase of EC value of soil was presumably due to the accumulation of continuous saline irrigation started from 0 WAP. The decrease 
Table 1. Rainfall, light intensity, air temperature, air humidity and wind speed

\begin{tabular}{lccccc}
\hline Month & $\begin{array}{c}\text { Rainfall } \\
\left(\mathrm{mm} \mathrm{month}^{-1}\right)\end{array}$ & $\begin{array}{c}\text { Light intensity } \\
(\text { lux })\end{array}$ & $\begin{array}{c}\text { Air temperature } \\
\left({ }^{\circ} \mathrm{C}\right)\end{array}$ & $\begin{array}{c}\text { Air humidity } \\
(\%)\end{array}$ & $\begin{array}{c}\text { Wind speed } \\
\left(\mathrm{km} \mathrm{h}^{-1}\right)\end{array}$ \\
\hline October-2016 & 324 & 1137 & 30.73 & 71.4 & 4.18 \\
November-2016 & 507 & 1093 & 29.03 & 71.28 & 3.57 \\
December-2016 & 708 & 2677 & 32.21 & 70.81 & 4.19 \\
January-2017 & 307 & 2109 & 32.17 & 71.15 & 4.19 \\
February-2017 & 361 & 2148 & 33.05 & 71.7 & 4.18 \\
\hline Average & 441.4 & 1832.8 & 31.44 & 71.27 & 4.06 \\
\hline
\end{tabular}

Source: Meteorology, Climatology and Geophysics Agency of Yogyakarta Province, 2016-2017

in $\mathrm{EC}$ value was suspected due to leaching by rain water. The average soil EC value measured at sunken-bed and at raised-bed were $2.03 \mathrm{dSm}^{-1}$ and $0.55 \mathrm{dSm}^{-1}$. The soil EC value measured at sunken-bed was higher than that at raised-bed. This was allegedly due to salt contained in irrigation water. The condition of sunken-bed receiving run-off from the saline irrigation coming from the raised-bed greatly contributed to the accumulation of salt in the sunken-bed. The position of sunken-bed enabled the soil condition to always be submerged, so that the sunken-bed was longer to be exposed to salt stress than the raised-bed. High and low salt content in water and soil was also affected by rainfall. The lower the rainfall, the higher the accumulation of salt as affected by saline irrigation. Conversely, the higher the rainfall, the salt content found in soil and water would be leached by rainwater and later that would decrease the EC value of the soil and water.

Table 2 showed that saline irrigation negatively affected the leaf area index (LAI) and photosynthetic rate. Leaf area index of rice grown at sunken-bed plants was lower than that of rice grown at raised-bed.
It was occurred due to high exposure of salinity stress on sunken-bed. The high concentration of soluble salt in soil greatly decreased the potential of the soil solution so that the plants dehydrated. The decreased rate of leaf growth after an increase in soil salinity is primarily due to the osmotic effect of the salt around the roots. Over days, reductions in cell elongation and also cell division lead to slower leaf appearance and smaller final size. Cell dimentions changes, with more reduction in area than depth, so leaves are smaller and thicker (Munns and Tester, 2008), and that it decreased the LAI. The low LAI would also decrease the photosynthetic rate.

Table 2 informed that saline irrigation negatively affected the photosynthetic rate of rice grown at sunken-bed. The photosynthesis was disrupted because of salt accumulation on the mesophyll tissue and the increased intercellular $\mathrm{CO} 2$ concentration (intercellular) that might reduce the stomatal opening (Da Silva et al., 2008). Continuous salt irrigation caused a rapid salt accumulation in the soil, decreased the osmotic potential of the soil solution and inhibited the plant to absorb water (Judge et al., 1986). Water

Table 2. Leaf area index (LAI) and photosynthetic rate of rice at 55 days after planting under raised- and sunken-bed system as affected by saline irrigation

\begin{tabular}{lcc}
\hline Treatment & LAI & $\begin{array}{c}\text { Photosynthetic rate } \\
\left(\mu \mathrm{mol} \mathrm{CO}_{2} \mathrm{~cm}^{-2} \mathrm{~s}^{-1}\right)\end{array}$ \\
\hline Nonsaline & $3.65 \mathrm{a}$ & $77.11 \mathrm{a}$ \\
Raised-bed (A1) & $3.60 \mathrm{a}$ & $72.61 \mathrm{a}$ \\
Sunken-bed (A0) & 3.62 & 74.86 \\
\hline Average & 22.94 & 3.52 \\
\hline CV (\%) & $2.31 \mathrm{p}$ & $78.28 \mathrm{p}$ \\
\hline Saline & $1.73 \mathrm{q}$ & $73.36 \mathrm{q}$ \\
Raised-bed (A1) & 2.02 & 75.82 \\
Sunken-bed (A0) & 7.62 & 1.41 \\
\hline Average & & \\
\hline CV (\%) & & \\
\hline Note $:$ Numbers in the same column followed by the same letter do not significantly different \\
$\quad$ according to the Tukey's HSD test at $\alpha=5 \%$ significance level.
\end{tabular}


is an essential material required by the plants in order to maintain photosynthesis, to be used for the formation of plant dry matter, as well as to develop the organ growth. Due to salinity stress, a decrease in the photosynthetic rate would negatively affect the total plant dry weight (Table 3). Approximately 80-90\% of the dry matter produced by photosynthesis (Yoshida, 1981).

The main indicator used in the investigation of plant tolerance against environmental stress is the root growth. Saline irrigation significantly affected the root length of rice grown at raised- and sunkenbeds. As affected by saline irrigation, the root length of rice grown at sunken-bed was shorter than that of rice grown at raised-bed. The extensive and long roots are common characteristics of salt-resistant plant. The responses root cells need to make are necessary not only to maintain their own correct function in the face of the new elevated external $\mathrm{Na}^{+}$, but also for them to signal to the shoot that shoot function must be altered (Munns and Tester, 2008). The root will naturally exploit and grow into nonsaline soil layers (Table 3 ).

The results also showed that the root of rice grown at raised-bed was longer than that of rice grown at sunken-bed under saline condition. The longer root of rice grown at raised-bed occurred because the plant growth was not impaired or it could be attributed to the drier conditions at raisedbed, there by stimulated the roots to grow longer to obtain water. This one was classified as a mechanism of drought resistance in plant (Table 3). Table 4 showed that saline irrigation and nonsaline had no significant effect on chlorophyll content.

$\mathrm{NaCl}$ is the main salt contained in the saline soil. When dissolved in water, $\mathrm{NaCl}$ will become its

Table 3. Total plant dry weight and root length of rice at 55 days after planting under raised- and sunken-bed system as affected by saline irrigation

\begin{tabular}{lcc}
\hline Treatment & $\begin{array}{c}\text { Total plant dry weight } \\
(\mathrm{g})\end{array}$ & $\begin{array}{c}\text { Root length } \\
(\mathrm{cm})\end{array}$ \\
\hline Non-saline & $30.27 \mathrm{a}$ & $3050 \mathrm{a}$ \\
Raised-bed (A1) & $28.09 \mathrm{a}$ & $1943.33 \mathrm{~b}$ \\
Sunken-bed (A0) & 29.18 & 2496.67 \\
\hline Average & 5.42 & 1.89 \\
\hline CV (\%) & $15.71 \mathrm{p}$ & $1558.33 \mathrm{p}$ \\
\hline Saline & $15.33 \mathrm{p}$ & $1146.67 \mathrm{q}$ \\
Raised-bed (A1) & 15.52 & 1352.5 \\
Sunken-bed (A0) & 8.46 & 5.51 \\
\hline Average & & \\
\hline CV (\%) & & \\
\hline Note $:$ Numbers in the same column followed by the same letter do not significantly different \\
$\quad$ according to the Tukey's HSD test at $\alpha=5 \%$ significance level.
\end{tabular}

Table 4. Chlorophyll a, chlorophyll b, and total chlorophyllcontent of rice at 55 days after planting under raisedand sunken-bed system as affected by saline irrigation

\begin{tabular}{|c|c|c|c|}
\hline Treatment & $\begin{array}{l}\text { Chlorophyll a } \\
\left(\mathrm{mg} \mathrm{g}^{-1} \mathrm{FW}^{*}\right)\end{array}$ & $\begin{array}{l}\text { Chlorophyll b } \\
\left(\mathrm{mg} \mathrm{g}^{-1} \mathrm{FW}^{*}\right)\end{array}$ & $\begin{array}{l}\text { Total chlorophyllcontent } \\
\qquad\left(\mathrm{mg} \mathrm{g}^{-1} \mathrm{FW}^{*}\right)\end{array}$ \\
\hline \multicolumn{4}{|l|}{ Non-saline } \\
\hline Raised-bed (A1) & $0.46 \mathrm{a}$ & $0.55 \mathrm{a}$ & $1.02 \mathrm{a}$ \\
\hline Sunken-bed (A0) & $0.45 \mathrm{a}$ & $0.54 \mathrm{a}$ & $0.99 \mathrm{a}$ \\
\hline Average & 0.46 & 0.55 & 1.01 \\
\hline CV (\%) & 11.73 & 18.26 & 15.19 \\
\hline \multicolumn{4}{|l|}{$\overline{\text { Saline }}$} \\
\hline Raised-bed (A1) & $0.48 \mathrm{p}$ & $0.59 \mathrm{p}$ & $1.07 \mathrm{p}$ \\
\hline Sunken-bed (A0) & $0.44 \mathrm{p}$ & $0.55 \mathrm{p}$ & $0.98 \mathrm{p}$ \\
\hline Average & 0.46 & 0.57 & 1.03 \\
\hline$\overline{C V}(\%)$ & 9.83 & 11.67 & 10.85 \\
\hline
\end{tabular}

Note : Numbers in the same column followed by the same letter do not significantly different according to the Tukey's HSD test at $\alpha=5 \%$ significance level. 
Table 5. Leaf $\mathrm{Na}+$ and $\mathrm{K}+$ concentration of rice at 55 days after planting (DAP) and at harvest time under raised- and sunken-bed system as affected by saline irrigation

\begin{tabular}{|c|c|c|c|c|}
\hline \multirow[t]{2}{*}{ Treatment } & \multicolumn{2}{|c|}{$\begin{array}{l}\text { Leaf } \mathrm{Na}^{+} \text {concentration } \\
\quad\left(\mathrm{mmol} \mathrm{g}^{-1} \mathrm{FW}^{*}\right)\end{array}$} & \multicolumn{2}{|c|}{$\begin{array}{l}\text { Total chlorophyllcontent } \\
\qquad\left(\mathrm{mg} \mathrm{g}^{-1} \mathrm{FW}^{*}\right)\end{array}$} \\
\hline & 55 DAP & at harvest time & 55 DAP & at harvest time \\
\hline \multicolumn{5}{|l|}{ Non-saline } \\
\hline Raised-bed (A1) & $0.46 \mathrm{a}$ & $0.55 \mathrm{a}$ & $1.02 \mathrm{a}$ & $27.78 \mathrm{a}$ \\
\hline Sunken-bed (A0) & $0.45 \mathrm{a}$ & $0.54 \mathrm{a}$ & $0.99 \mathrm{a}$ & $18.21 \mathrm{a}$ \\
\hline Average & 0.46 & 0.55 & 1.01 & 22.99 \\
\hline$\overline{\mathrm{CV}(\%)}$ & 11.73 & 18.26 & 15.19 & 18.45 \\
\hline \multicolumn{5}{|l|}{ Saline } \\
\hline Raised-bed (A1) & $0.48 \mathrm{p}$ & $0.59 \mathrm{p}$ & $1.07 \mathrm{p}$ & $25.73 \mathrm{q}$ \\
\hline Sunken-bed (A0) & $0.44 \mathrm{p}$ & $0.55 \mathrm{p}$ & $0.98 \mathrm{p}$ & $36.94 \mathrm{p}$ \\
\hline Average & 0.46 & 0.57 & 1.03 & 31.33 \\
\hline$\overline{\mathrm{CV}(\%)}$ & 9.83 & 11.67 & 10.85 & 1.57 \\
\hline
\end{tabular}

Note : Numbers in the same column followed by the same letter do not significantly different according to the Tukey's HSD test at $\alpha=5 \%$ significance level. *FW: fresh weight

constituent ions, $\mathrm{Na}^{+}$and $\mathrm{Cl}^{-}$. The high concentration of $\mathrm{Na}^{+}$will increase the $\mathrm{EC}$ value of the soil especially in the sunken-bed. Table 5 showed that saline irrigation significantly affected the high leaf $\mathrm{Na}^{+}$concentration at harvest time. Leaf $\mathrm{Na}^{+}$concentration of rice grown at sunken-bed increased and was significantly greater than that of rice grown at raise-bed. The accumulation of leaf $\mathrm{Na}^{+}$was significantly different when the plant reached the generative phase. It was suspected due to saline irrigation that was regularly causing salt accumulation from the age of 55 days after planting to harvest. The declined rainfall until the harvest time was also suspected to cause high salt accumulation, so that the $\mathrm{Na}^{+}$concentration of rice grown at sunken-bed was significantly different compared to that of rice grown at raised-bed at harvest.

Table 5 showed the leaf $\mathrm{K}^{+}$concentration decreased with increasing $\mathrm{Na}^{+}$concentration. The effect of $\mathrm{Na}^{+}$ is often indirect to the plant because it is antagonistic to other elements. High $\mathrm{Na}^{+}$levels inhibit $\mathrm{K}^{+}$uptake. The increase of $\mathrm{Na}^{+}$concentration will negatively affect the tissue $\mathrm{K}^{+}$concentration. The higher the tissue $\mathrm{Na}^{+}$accumulation, the lower tissue $\mathrm{K}^{+}$concentration. It was in accordance with the experimental result from 55 days after planting to harvest which showed that the increase of $\mathrm{Na}^{+}$concentration decreased $\mathrm{K}^{+}$ (Table 5). Flowers et al. (2015) said that high $\mathrm{Na}^{+}$ concentrations will cause $\mathrm{K}+$ not to approach the root zone, and then cannot be absorbed properly by the plants. This causes the plant to be deficient in $\mathrm{K}^{+}$ which has several important roles for the plant. $\mathrm{K}^{+}$ in plants acts as an enzyme activator in the process of photosynthesis, protein and carbohydrate metabolism, helps the translocation of carbohydrates, protein synthesis and maintains its stability, increases plant resistance to disease, increases seed size, as well as improves the quality of fruits and vegetables.

Leaf proline concentration of rice grown at sunken-bed was higher under saline conditions compared to that of rice grown at raised-bed. It was suspected due to a higher salt accumulation that was more routinely occurred in sunken-bed. Hence, plant performed a defensive mechanism by increasing the proline concentration in the plant tissue (Table 6).

High concentration of $\mathrm{Na}^{+}$was likely to be toxic to plants, thus initiating the plant to adapt and to enhance their endurance against the environmental stress. The accumulation of proline is the plant's first response to salinity stress in order to reduce cell damage (Ashraf and Foolad, 2007). Generally, proline is

Table 6. Leaf proline concentration of rice under raisedand sunken-bed system as affected by saline irrigation

\begin{tabular}{lc}
\hline Treatment & $\begin{array}{c}\text { Leaf proline concentration } \\
\left(\mu \mathrm{mol} \mathrm{hill} \mathrm{H}^{-1} \mathrm{FW}^{*}\right)\end{array}$ \\
\hline Non-saline & $970.6 \mathrm{~b}$ \\
Raised-bed (A1) & $2358.5 \mathrm{a}$ \\
Sunken-bed (A0) & 1664.58 \\
\hline Average & 15.64 \\
\hline CV & $1007.8 \mathrm{q}$ \\
\hline Saline & $2569.2 \mathrm{p}$ \\
Raised-bed (A1) & 1788.29 \\
Sunken-bed (A0) & 7.99 \\
\hline Average & CV
\end{tabular}

Note : Numbers in the same column followed by the same letter do not significantly different according to the Tukey's HSD test at $\alpha=5 \%$ significance level. *FW: fresh weight 
Table 7. Harvesting age (days after sowing), grain weight and dry grain yield (DGY) of rice under raised-and sunken-bed system as affected by saline irrigation

\begin{tabular}{lccc}
\hline Treatment & Harvesting age (DAS) & $\begin{array}{c}\text { Grain weight } \\
\left(\mathrm{g} \mathrm{hill} \mathbf{l}^{-1}\right)\end{array}$ & $\begin{array}{c}\text { Dry grain yield (DGY) } \\
\left.\text { (ton ha }^{-1}\right)\end{array}$ \\
\hline Non-saline & $125.0 \mathrm{a}$ & $28.94 \mathrm{a}$ & $5.25 \mathrm{a}$ \\
Raised-bed (A1) & $119.0 \mathrm{~b}$ & $32.60 \mathrm{a}$ & $6.78 \mathrm{a}$ \\
Sunken-bed (A0) & 122.00 & 30.77 & 6.02 \\
\hline Average & 0.00 & 12.82 & 14.99 \\
\hline CV (\%) & $119.0 \mathrm{p}$ & $14.45 \mathrm{p}$ & $4.29 \mathrm{p}$ \\
\hline Saline & $113.0 \mathrm{q}$ & $13.81 \mathrm{p}$ & $2.86 \mathrm{p}$ \\
Raised-bed (A1) & 116.00 & 14.13 & 3.58 \\
Sunken-bed (A0) & 0.00 & 20.71 & 23.37 \\
\hline Average & CV (\%) & & \\
\hline
\end{tabular}

Note : Numbers in the same column followed by the same letter do not significantly different according to the Tukey's HSD test at $\alpha=5 \%$ significance level.

accumulated in salt-stressed plant tissue and plays an important role in the regulation of osmotic pressure and antioxidants in cells (Cha-um et al., 2010). The proline acts as an osmoregulator to regulate the turgor and cell volume through the osmotic adjustment. The proline is accumulated in the cytoplasm without causing toxicity (Munns and Tester, 2008). The accumulation of proline is a form of plant resistance mechanism to osmotic stress that acts to regulate and balance the osmotic value of the cell compartment, so that the turgor pressure inside the cell is maintained and it keeps protecting enzymes during stress. Consequently, the plant metabolism still undergoes well. The accumulation of proline may decrease the osmotic potential and later decreased the cell water potential without limiting the function of enzymes and maintaining cell turgor (Hamim, 2004). Proline protects plants from stress by stabilizing cell membranes and maintaining turgor pressure (Hapsoh et al., 2006).

Table 7 showed that the saline irrigation significantly affected the harvesting. The harvesting age of rice grown at sunken-bed was more rapid ( \pm 1 week) than that of rice grown at raised-bed. As presented in Table 7 , nonsaline and saline irrigation did not significantly affected dry grain yield (DGY), either for rice grown at sunken-bed or at raised-bed. It was suspected that photosynthesis products were more widely used for root and shoot growth so that the weight of DGY was not significantly different.

\section{CONCLUSIONS}

Saline irrigation combined with raised- and sunkenbed greatly affected leaf area index (LAI), photosynthetic rate, root length, leaf proline concentration, leaf $\mathrm{Na}^{+}$ and $\mathrm{K}+$ concentration at harvest time and harvesting age. Saline irrigation lowered LAI, photosynthetic rate and root length of rice grown at sunken-bed. Contrastingly, leaf $\mathrm{Na}^{+}$concentration and leaf proline concentrations of rice grown at sunken-bed were higher compared to that of rice grown at raised-bed. The leaf $\mathrm{K}+$ concentration decreased within creasing $\mathrm{Na}+$ concentration. Although saline irrigation and nonsaline irrigation could accelerate harvesting age of rice grown at sunken-bed, the dry grain yield (DGY) of rice grown at sunken-bed did not significantly different from that of rice grown at raised-bed.

\section{ACKNOWLEDGEMENT}

The author express her deep gratitude to the Ministry of Research, Technology and Higher Education Republic of Indonesia (Riset DIKTI) for the funding provided to this research.

\section{REFERENCES}

Ashraf, M and M.R. Foolad. 2007. Improving Plant Abiotic-stress Resistance by Exogenous Application of Osmoprotectants Glycine Betain and Proline. Journal Environment Experiment Botany 59.

Atamaja, Ruslia. 2013. Planting with Surjan System in Tidal Land. Agricultural Research Institute of Swamp Land (Balittra)-Agricultural Research Agency. http://cybex.pertanian.go.id. (Accessed May, 9 2017)

Cha-um, S., M. Ashraf and C. Kirdmanee. 2010. Screening Upland Rice (Oryza sativa L. ssp. Indica) Genotypes for Salt-Tolerance Using Multivariate Cluster Analysis. African Journal of Biotechnology. 9(30).

Chinnusamy, V., A. Jagendorf and J. K. Zhu. 2005. Understanding and improving salt tolerance 
in plants. Crop Sci, 45: 437-48.

Da Silva, E.C., R.J.M.C. Nogueira, F. P. De Araujo, N. F. De Melo and A. D. De Azevedo Neto. 2008. Physiological Respon to Salt Stress in Young Umbu Plants. Journal Environmental and Experimental Botany.

FAO. 2005. FAO Field Guide 20 things to know about the impact of sea water on agricultural land in NAD Province. http://www.fao.org. (Accessed, December 15, 2016).

Flowers, T.J. and T. D. Colmer. 2015. Plant salt tolerance: adaptations in halophytes. Annals of botany, 115(3), pp.327-331.

Gardner, F.P., R. B. Pearce and R. L. Mitchell. 1991. Physiology of Crop Plants. University of Indonesia Press.

Hamim. 2004. Underlaying Drought Stress Effects on Plants : Inhibition of Photosynthesis. Jurnal Hayati 11

Hapsoh. 2006. Physiological Response Several Soybean Genotypes Symbiotic with MVA to Various Levels of Drought Relief. Journal of Biology 13(2).

Hasanah, N.A.U. 2016. Growth and Yield of the three rice (Oryza sativa L.) cultivars at different levels of salinity on coastal sandy land. Thesis. Gadjah Mada University.

Levitt, J. 1980. Responses of Plant to Environmental Stresses 2nd ed.New York.Academic pr. 607 p.

Munns, R. and M. Tester. 2008. Mechanisms of salinity tolerance. Annu. Rev. Plant Biol., 59, pp.651-681.

Nazemi, D., A. Hairani and L. Indrayati. 2012. Prospects for Surjan Land System Development in Tidal Swamp Land. Agrovigor, 5(2), pp.113-118.
Rezaei, M., N. Davatgar, A. Ashrafzade, N. Pirmoradian, M. R. Khaledian, E. Amiri and M. Vazifedost. 2011. Intermittent Irrigation: AProcedure to Use Saline Water in Rice Cultivation. International Congress on Irrigation and Drainage, Teheran. Shaaban, M., M. Abid and R.A.I. Abou-Shanab. 2013. Amelioration of Salt Affected Soils in Rice Paddy System by Application of Organic and Inorganic Amendments. Plant Soil Environment 5.

Shannon, M.C., J. D. Rhoades, J. H. Draper, S. C. Scardaci and M. D. Spyres. 1998. Assessment of salt tolerance in rice cultivars in response to salinity problems in California Sci., 38: 394-398.

Sunghening, W. 2015. Characteristics Physiology and Yield Mung Bean (Vigna radiate, L.) at Different Shade Level at Bugel Coastal land, Kulon Progo. (Thesis). Gadjah Mada University. Tohari. 2017. Gravimetric Approach Method: A simple, rapid, and promising method for estimating root length and root surface area of rice crop using their root characteristic of dry weight, length, and root diameter. Personal Communication. December 28, 2017. Universitas Gadjah Mada.

Yoshida, S. 1981. Fundamentals of Rice Crop Science. The International Rice Research Institute.Los Banos, Philippines.

Zeng, L., M. C. Shannon and S. M. Lesch. 2001. Timing of salinity stress affects rice growth and yield components. Agric. Water Manage. 48: 191-206. 